\title{
Instrução, festas cívicas e a prática de Canto Orfeônico em tempos de Estado Novo no Piauí
}

\author{
Instruction, civic celebrations and the practice of Orpheonic \\ singing in times of Estado Novo in Piaui
}

José de Arimatéa Freitas Aguiar Júnior ${ }^{1}$

RESUMO

\begin{abstract}
Este trabalho apresenta um estudo sobre a instrução, às celebrações cívicas e a prática de canto orfeônico durante o Estado Novo no Piauí. Tendo como objetivo principal analisar como os estabelecimentos de ensino utilizaram esses recursos na busca da constituição da cultura cívica e na legitimação do novo regime. Para que essa proposta fosse contemplada, foram abordados, no texto, os investimentos que a educação piauiense recebeu no período, a construção de Grupos Escolares pelo Piauí, a participação dos estudantes nos eventos cívicos organizados pelas escolas, a implantação da prática do canto orfeônico nos estabelecimentos e, por fim, como a juventude piauiense se posicionou perante as normatizações e imposições das instituições, bem como do Estado Novo. Para a realização desse estudo, utilizamos o jornal Diário Oficial, relatórios governamentais, entrevistas com ex-alunos e fotografias. As categorias teórico-metodológicas utilizadas nas discussões sobre Estado Novo foram Gomes (2005), Schwartzman (1983) e Schwartzman; Bomeny; Costa (1984). Para as reflexões que norteiam os estudos sobre cidades nos debruçamos nos estudos de Nascimento (2002), Lopes (2007) e Solon (2006). No tocante a constituição da memória patriótica foi de fundamental importância às obras de Halbwachs (2003) e Pollak (1992).
\end{abstract}

Palavras chave: História. Estado Novo. Instrução. Festas Cívicas. Canto Orfeônico.

\section{ABSTRACT}

This work presents a study about the instruction, the civic celebrations and the practice of orpheonic singing during Estado Novo in Piauí. Its main objective is to analyze how educational institutions have used these resources in the search for the constitution of civic culture and the legitimation of the new regime. In order for this proposal to be contemplated, the text included the investments that Piauí education received during the period, the construction of School Groups by Piauí, the participation of students in civic events organized by schools, the implementation of the practice of singing in the Establishments and, finally, how the Piauían youth stood before the norms and impositions of the institutions, as well as the Estado Novo. In order to carry out this study, we used the newspaper Diário Oficial, government ${ }^{1}$-Universidade Federal do Piauí - UFPI 
reports, interviews with alumni and photographs. The theoretical-methodological categories used in the discussions about Estado Novo were Gomes (2005), Schwartzman (1983) and Schwartzman; Bomeny; Costa (1984). For the reflections that guide the studies on cities, we focus on studies by Nascimento (2002), Lopes (2007) and Solon (2006). As for the constitution of patriotic memory, it was of fundamental importance to the works of Halbwachs (2003) and Pollak (1992).

Keyword: History. New state. Instruction. Civic Festivals. Orfeônico Corner.

A partir de novembro 1937, as comemorações oficiais aumentaram e diversas delas foram incorporadas ao cotidiano dos escolares, cada vez mais solicitados a participar dos eventos cívicos que consagravam o "novo período" da história do país. Francisco Alcides do Nascimento ressalta que, com a implantação do Estado Novo, as comemorações das datas cívicas ganharam maior dimensão, além de ter seu número aumentado. $O$ autor afirma ainda que esse tipo de comunicação, segundo os seus mentores, tinha como objetivo desenvolver, especialmente entre os jovens, o espírito cívico (NASCIMENTO, 2002, p. 18).

Nessa mesma perspectiva, Ângela de Castro Gomes constata que, somente a partir do Estado Novo, a figura de Getúlio Vargas começa a ser projetada como a de um grande e indiscutível líder nacional. Em 1938, o DIP começa a se dedicar exclusivamente à imagem do regime e de seu chefe, personagem central durante a realização de comemorações e solenidades em todo o país. Festividades, cartazes, fotografias, artigos, concursos escolares e toda uma enorme gama de iniciativas foram empreendidas em louvor ao chefe do Estado Novo. Seu nome e sua imagem passaram a partir daí a encarnar o regime e todas as suas realizações (GOMES, 2005, p. 219).

Em nível local, sob a supervisão do Departamento Estadual de Imprensa e Propaganda, caberia aos piauienses promoverem celebrações em momentos considerados significativos, investindo-se, assim, na difusão e legitimação do novo regime, bem como celebrar o que a interventoria local executava nos diversos âmbitos, inclusive na educação.

Para Antônio de Pádua Carvalho Lopes, as festas eram de diferentes tipos e motivações. No Piauí, foi especialmente com o advento das escolas reunidas e dos Grupos Escolares que a rotina de festas se expandiu e se consolidou. Reunião e movimentação de um número significativo de alunos, as festas escolares demarcavam mobilidade e status das escolas na cidade (LOPES, 2007, p. 11).

No ano de 1935, durante a realização dos festejos religiosos, na cidade de Barras no Piauí, foram inaugurados um Grupo Escolar e o jardim público "Monsenhor Boson", na presença do governador Leônidas de Castro Melo e do Diretor do Departamento de Ensino, Dr. Anísio Britto. Estes estariam levando vários melhoramentos à educação piauiense, em diversas cidades do estado, construindo grupos escolares para abrigar o ensino primário. No caso de Barras, "O Grupo Escolar inaugurado é o typo dos edifícios escolares mandados construir pelo governo 
do Estado em vários municípios. Apresenta linhas muito agradáveis, sendo espaçoso e bastante arejado" (A INAUGURAÇÃO, 1935, p. 8).

É interessante perceber que as inaugurações em Barras aconteceram durante as tradicionais festas da padroeira da cidade, ocasião em que o município estava envolvido em várias programações festivas e aglomerava seus moradores e demais pessoas de municípios vizinhos para contemplarem os melhoramentos e recepcionarem a comitiva do governo.

O governador Leônidas Melo, segundo o discurso oficial, incentivava a educação no Piauí em diversos níveis, inclusive no âmbito privado. Em 1936, o Diário Oficial noticiou a inauguração do pavilhão destinado ao Jardim de Infância do Colégio "Sagrado Coração de Jesus", colégio dirigido pelas irmãs de Santa Catarina de Senna, estava passando por melhoramentos, devido aos esforços dos seus responsáveis e do governador. Este inclusive era homenageado na ocasião festiva:

Hoje, queremos nos ocupar, aliás com grande satisfação, unicamente do elegante e bem construído pavilhão destinado ao Jardim da Infância o qual foi inaugurado hontem às 16:30 horas sob grande demonstração de jubilo por parte de professores e alumnos. [...] Primeiramente verificou-se a benção por D. Severino Vieira de Mello, Bispo do Piauhy, de uma imagem do Menino Jesus. Em seguida a esta cerimônia, que se revestiu de grande solenidade, foi inaugurado no pavilhão um retrato do Sr. Leônidas Melo, honrado Governador do Estado, como um tributo de gratidão pelo muito que há feito em prol do Colégio em geral e em particular do Jardim da Infância (COLÉGIO, 1936, p. 1, 12).

Teresina era apontada como uma capital que necessitava de um teto que obedecesse aos preceitos da moderna pedagogia para amparar a educação infantil. A superiora do estabelecimento educacional, Maria Catharina Levrini e o governador Leônidas Melo, foram apontados como os anfitriões da festa de gratidão que acontecia no Colégio "Sagrado Coração de Jesus". ${ }^{1}$ Falou na ocasião a aluna Ernestina Leal, aluna do $3^{\circ}$ ano do Curso Normal, ela frisou os esforços do Dr. Leônidas Melo em benefício do Colégio. O governador agradeceu aquela homenagem que lhe era prestada, externando grande satisfação na inauguração do novo pavilhão. Foram ouvidos, em seguida, diversos números de cânticos dos alunos do Jardim de Infância, tendo logo após as alunas do Curso Normal executado ginásticas diversas, e por fim, todos cantaram o Hino do Brasil (COLÉGIO, 1936, p. 1, 12).

Ocorreu uma solenidade no salão nobre da prefeitura de Teresina, no dia 04 de fevereiro de 1939, organizada pelo Prefeito Lindolfo do Rego Monteiro e demais funcionários ao Interventor Leônidas Melo. A solenidade foi transmitida pela Amplificadora Teresinense. No discurso

\footnotetext{
${ }^{1} \mathrm{O}$ colégio Sagrado Coração de Jesus, popularmente conhecido como Colégio das Irmãs, foi fundado em 1906 como parte do esforço inicial de renovação da igreja no Piauí e destinou-se, no inicio, a ser um espaço para absorção do alunado feminino oriundo das camadas abastadas de Teresina e do interior do Estado (QUEIROZ, 2008. p. 67).
} 
do Prefeito de Teresina percebemos quanto a instrução pública vinha recebendo amparo no período citado:

O Sr. Interventor Leônidas Melo, senhores, dispensa, como lhe é peculiar carinho ao Departamento da Instrução Pública, sobejamente provado por vários motivos e títulos. Esse carinho vem também do fato de ser o nosso eminente chefe um professor, que encara o problema da instrução de modo positivo, necessário e indispensável à organização da vida do Estado. Ninguém, repito, cuidou e cuida mais da instrução, entre nós, do que S. Excia. [...] Grande tem sido o seu cabedal de recursos para facilitar a abertura de um apreciável número de escolas. Por toda parte levantam-se edifícios escolares padronizados. Nos mais longínquos recantos do sul, as escolas são abertas aos meninos em idade escolar, como só acontecia entre nós, em Teresina, ou no Norte. O número de matrículas sobe, vertiginosamente, ano a ano, diminuindo, assim, aquele espantalho de analfabetos [...]. Só na administração Leônidas Melo, o número de crianças nas escolas, de 7 a 14 anos, subiu de 22 mil para 34 mil. Destaquemos, também, a instrução secundária ministrada no majestoso edifício do Liceu Piauiense que honra, sobremodo, não só o Piauí, como todo o território brasileiro, condizendo, perfeitamente, com as suas elevadas finalidades. Não esqueçamos o modo carinhoso com que S. Excia. encara o ensino normal, dando-lhe todo o apoio necessário ao seu bom funcionamento. E, também, ao superior, emprestando à nossa notável Faculdade de Direito, tudo aquilo que se fez mister, ultimamente, para a reabertura dos seus cursos, de cujos bancos acadêmicos tem saído bacharéis que em nada desmerecem dos seus colegas mais distintos das escolas congêneres do país (MONTEIRO, 1939, p. 1-4).

A partir do exposto acima, percebemos o quanto a instrução pública recebia investimentos do governo de Leônidas Melo. Este, segundo o conferencista, não descuidava de nenhum nível educacional do Estado, amparava a educação primária, secundária, o ensino normal e o superior. Essa imagem de Leônidas Melo como "protetor da educação" pode ser percebida nas memórias de uma ex-aluna da Escola Normal Oficial de Teresina, Dona Raimunda de Carvalho Sousa, que ingressou na Escola Normal em 1942. A ex-normalista recorda a sua iniciativa em adquirir livros, que despertou a atenção de outros jovens no período:

Eu me lembro tanto na época das listas dos livros que a gente recebia na Escola, que era aquela lista enorme de livro de tudo em quanto era disciplina e se você não tivesse aqueles livros você tinha que tomar apontamento de aula e tudo, eu disse: "eu vou pedir, eu vou lá na casa do governador pedir livro", e fui e ele deu. Mandou dar tudo quanto foi livro e ai pronto todo mundo que soube da história 
que precisava de livro ia atrás e ele dava. Mandava pra Chefatura de Polícia, me lembro do nome do Chefe de Polícia Coronel Evilásio Vilanova, atendia a gente na maior presteza do mundo, aquilo ali quando a gente chegava e dizia: "é aluno?" e dizia: "é”. Ele mandava lá pra uma sala, ai lá naquela sala ele mandava uma pessoa anotar o nome da gente e a nota do livro da gente, ai marcava o dia pra gente ir no almoxarifado, ai a gente recebia tudim [comemora batendo palma]. Até material de desenho ele dava, me lembro demais dessa dignidade do governo Leônidas Melo. [...] Ele mandava distribuir e mandava dar tudim na Tipografia Popular, entregava o material todinho e depois ele mandava pagar. Era aluna da Escola Normal nesse tempo, era livro de tudo em quanto era disciplina que a gente precisava, tivesse naquela nota você recebia, até os compassos, transferidor, lápis de cor, tudo vinha no kit de escola, me lembro disso demais que ele fez Leônidas Melo (SOUSA, 2013).

Segundo a entrevistada, que era do município de Timon no Maranhão, naquele tempo existiam muitas pessoas pobres, que não tinham condições de adquirir os livros da Escola Normal. Ela temendo ter seus estudos comprometidos em uma instituição bastante reconhecida no Piauí, teve a iniciativa de buscar ajuda com o Interventor piauiense. Este chegou a montar um kit escola, para auxiliar os alunos que tivessem dificuldades em adquirir material escolar no período.

A criação do Ministério da Educação e Saúde, no ano de 1930, tendo como ministro Gustavo Capanema (1934-1945), gerou grande impulso aos trabalhos relativos a estes dois campos. Empreenderam-se no novo Ministério todos os elementos de ação para a realização de uma obra de alcance nacional. Desse modo, “[...] o antigo caos e anterior dispersão dos serviços educacionais cedem lugar a um sistema nacional, coeso e funcional, que comunica a todas as instituições e aparelhos do nosso ensino uma mesma dinâmica e um só sentido" (SCHWARTZMAN, 1983, p. 355-359).

Nas décadas de 1930 e 1940, durante os governos de Landri Sales ${ }^{2}$ e Leônidas Melo ${ }^{3}$ aconteceu a construção de diversas escolas, sobretudo Escolas Agrupadas e Grupos Escolares, em várias cidades piauienses (PIAUÍ, 1938, p. 85-86). E o momento de inauguração das escolas era largamente divulgado pela imprensa oficial e, costumeiramente, se realizavam as solenidades inaugurais em datas específicas do calendário político do Estado.

No ano de 1939, durante as comemorações do quarto aniversário do governo de Leônidas Melo, houve um banquete oferecido ao Interventor piauiense pelos municípios do Estado. É interessante perceber que através da conferência do prefeito de Teresina, Lindolfo Monteiro, o Piauí estava recebendo atenção especial, sobretudo na construção de escolas por todo o Estado:

${ }^{2}$ Landri Sales governou o Piauí de 21 de maio de 1931 até o dia 03 de maio de 1935.

${ }^{3}$ Leônidas de Castro Melo foi governador do Piauí de 03 de maio de 1935 até 09 de novembro de 1945. 
[...] Sinto-me grandemente envaidecido com a incumbência que ora me acho investido. Falo em nome de todos os municípios piauienses. Interpreto o seu júbilo e o seu sentimento. [...] Todos os municípios tem recebido do atual governo grandes benefícios, no que tange à Instrução. Assim é que já foram inaugurados edifícios escolares em diversas edilidades. Grupos escolares em Barras, Piracuruca, Pedro II, Oeiras, Porto Alegre, Parnaíba, José de Freitas, União e com via de acabamento nos municípios de Floriano, Valença e São Pedro. Escolas Agrupadas em Castelo, Belém, Boa Esperança, Aparecida, Socorro, Regeneração, Santa Filomena, Canto do Buriti, Luiz Correia e em Morros da Mariana. Escolas Nucleares atinjem a quasi duzentas. No de Teresina o ensino primário, secundário e superior muito deve ao eminente chefe (MONTEIRO, 1939, p. 1).

Percebemos que o governo estadual estava construindo prédios escolares em diversas localidades do Piauí. O tipo de construção mais adotada no período foram os Grupos Escolares. Cidades como Barras, Piracuruca, Oeiras, Parnaíba e União ganharam seus prédios escolares para abrigar as crianças que necessitavam receber instrução primária, naquela época em que os índices de analfabetismo ainda eram elevados. No entanto, o governo piauiense confiou à empresa Hollerith o levantamento do censo escolar, o que mereceu do Ministro Capanema elogios aos índices crescentes da educação no Piauí (MONTEIRO, 1939, p. 1).

No mesmo ano a comitiva interventorial visitou o município de Valença para a inauguração do edifício do Grupo Escolar "Cônego Acilino" e a visita ao Hospital São Vicente de Paula. A construção do Grupo Escolar adveio de iniciativas do Prefeito de Valença, Jaime Nogueira e do amparo material do interventor piauiense. À inauguração compareceram autoridades de Valença e outros municípios, alunos de escolas públicas, estudantes do Colégio São José e a população da cidade. Na fotografia a seguir, podemos visualizar diversos aspectos da solenidade ocorrida em Valença: 


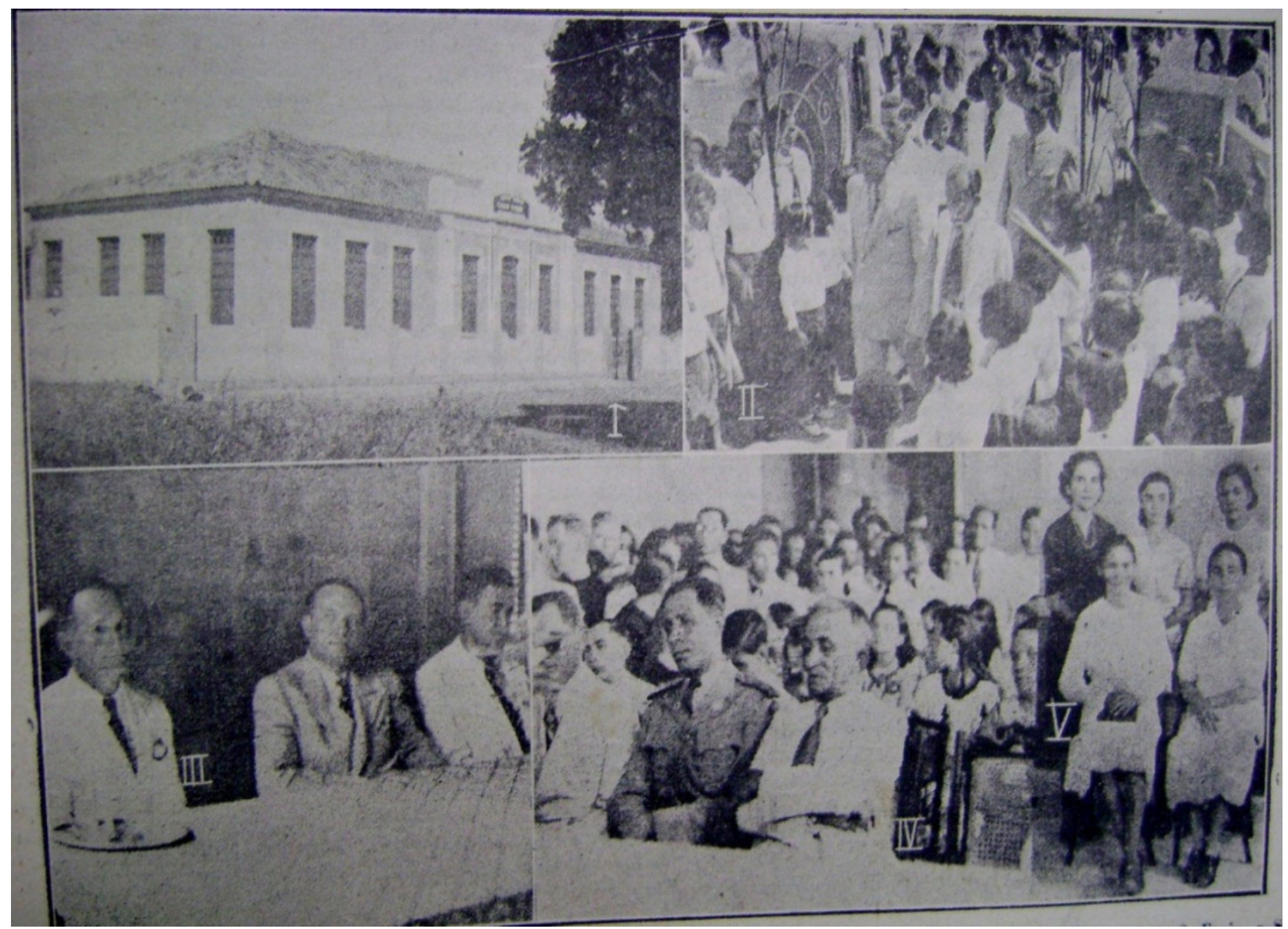

Fotografia 1 - Inauguração do Grupo Escolar “Cônego Acilino” em Valença. Fonte: (A INAUGURAÇÃO, 1939, p. 1).

Percebemos a partir da fotografia, os diversos momentos que envolviam as inaugurações em cidades do Piauí, comprovando os melhoramentos empreendidos pelas autoridades estaduais e municipais em garantir assistência educacional em suas localidades. No caso de Valença, por ocasião da inauguração do Grupo Escolar, as professoras e estudantes recebiam as autoridades com palestras e realizavam aglomerações nos locais recém construídos para prestarem suas homenagens.

Na conferência proferida pelo orador oficial da solenidade, Dr. Sales Lopes, Juiz de Direito de Valença, ele constata a importância da inauguração do edifício escolar:

A solenidade inaugural do Grupo Escolar "Cônego Acilino", é de grande regozijo para os habitantes desta legendária cidade, e quiça, de todo Piauí, pois é um 
grande passo dos poderes Estadual e Municipal, conjugados para o desenvolvimento cada vez mais crescente da difusão da instrução em todo o Estado (LOPES, 1939, p. 1-3).

Além do orador oficial, discursou o Juiz de Direito de Picos, Dr. Sátiro Nogueira, o Dr. Anísio de Brito Melo, Diretor do Departamento de Ensino, além de alunas como Gercina Soares dos Santos, do $4^{\circ}$ ano primário e Maria de Lemos, do Colégio São José. A professora Idalina Ferreira da Silva foi outra conferencista na ocasião da inauguração do Grupo Escolar em Valença. Ela destacou o novo ambiente escolar que estava em consonância com as prerrogativas do Estado Novo:

[...] a educação não se constitui apenas do duplo humano, representado em professores e alunos. Ela é, na realidade, um conjunto muito mais amplo, mais complexo e mais importante. Para os objetivos, a que se destina, pressupõe a existência de numerosos e imprescindíveis elementos vitais. [...] o ambiente é, sem dúvida, o fator de suma importância entre os demais. [...] A casa de ensino, por isso mesmo, não pode apresentar-se sem as condições que a higiene prescreve como necessárias a saúde, a pedagogia recomenda como fundamentais à higidez do espírito e a estética impõe como indispensáveis ao estímulo dos sentidos bem orientados. É por esta razão, sempre louvável a política de construção de prédios escolares, que contribuam para a consecução prática dos intuitos educativos. Não há como negar que o espírito se areja, como se lhe abrissem janelas ensolaradas, num ambiente de limpeza, sobriedade de linhas e propriedade de acomodações. Os casarões antigos, a que se recolhiam nossas escolas públicas até poucos anos, eram nocivos aos propósitos da educação. Ausência da alegria, das coisas limpas, excesso ou deficiência de luz, impropriedade de cômodos, todas elas contribuíam para tornar o ensino mais pesado e mais denso. Hoje não. Tudo se renova ao sopro das realizações creadoras (SILVA, 1939, p. 3).

Ao tempo em que a professora elogia a construção do novo Grupo Escolar, que estaria dentro dos padrões que era desenvolvido em todo o Brasil, ela denuncia como o ensino era praticado nos casarões destinados à educação pública piauiense antes da década de 1930, em ambientes de pouca luminosidade e em salas que causavam desconforto aos estudantes do período. Durante muito tempo o ensino aconteceu em casarões alugados, ambientes desprovidos de diversos recursos que garantissem a qualidade e a efetiva aprendizagem da juventude piauiense.

Outra forma de educar, que deveria ganhar destaque e apoio dos educadores brasileiros nas décadas de trinta e quarenta, era a educação dos sentidos. Segundo a professora Maria Cacilda 
Ribeiro Gonçalves, ${ }^{4}$ os estudantes brasileiros recebiam, até pouco tempo, uma educação superficial, fazendo com que o alunado fosse visto como bonecos manipulados. Para ter-se uma educação satisfatória seria necessário passar pelos níveis físico, intelectual e por fim ter uma educação que atingisse os sentidos:

A civilização, não resta dúvida, esta se desenvolvendo em todos os recantos da terra, mas até chegar o dia em que a vontade do homem se ache de tal forma educada de modo a se impor e vencer a brutalidade do caracter, dominando os instinctos rudes da animalidade, muito temos, ainda, que trabalhar e soffrer. Os sentidos, que estão diretamente ligados ao systema nervoso, são instrumentos da alma, as forças activas do mundo exterior, e, por isso, a luz, o som, o calor, produzem nelles a excitação dos nervos sensitivos que estes transmitem até o cérebro. E como este é a força accionante dos nossos movimentos, devem os sentidos merecer, de nossa parte, especial cuidado na sua educação (GONÇALVES, 1936, p. 1, 5).

Segundo a professora Maria Cacilda Ribeiro Gonçalves, a Instrução só seria completa se estivesse aliada à "educação dos sentidos", assim os estudantes teriam uma completa consciência de si e de seus atos, inclusive de suas influências no meio político-social. Para a professora não bastava instruir, era preciso educar. A instrução enriqueceria o espírito de conhecimentos e revigorava a capacidade de raciocínio, mas seria a educação que preparava as pessoas para viver em sociedade, dando ciência e consciência de seus direitos e deveres para com a família e a Pátria.

Maria Cacilda Ribeiro Gonçalves baseava-se nas recomendações do professor Oscar Lourenzo Fernandez, do Instituto Nacional de Música do Rio de Janeiro, que apontava a necessidade da arte como um fator que gerava unidade, sobretudo a música, pela qual os brasileiros eram tão afeiçoados:

[...] A finalidade máxima do Estado, em matéria artística, deve ser a da nacionalização e desenvolvimento intensivo e extensivo da Arte, que é a cúpula cultural de todos os grandes povos. Indiscutivelmente, a música está, forçosamente, colocada no primeiro plano entre os elementos que maior efficiência podem ter na educação dos sentidos, especialmente da audição e da vista. Com uma animação divina, acorda as nossas vibrações adormecidas, desperta as nossas aspirações pela alegria de viver, purifica os nossos sentimentos, activa as nossas energias cívicas, incentiva o nosso amor à terra natal, encorajando-nos, portanto a luta pela grandeza da Pátria [...]. Se perlustrarmos, porém, com o devido critério, a cultura brasileira sob o ponto

\footnotetext{
${ }^{4}$ Maria Cacilda Ribeiro Gonçalves foi professora da Escola Normal Oficial de Teresina.
} 
de vista artístico, notaremos, entristecidos, o abandono em que se tem deixado a música, na maioria dos Estados, inclusive o Piauhy (GONÇALVES, 1936, p. 1, 5).

A partir do exposto podemos perceber o pouco incentivo e o abandono em que o ensino de música enfrentava em todo o país, inclusive no Piauí. E as canções cívicas tinham esse poder de despertar sentimentos que estavam adormecidos, adentrando na mente e no coração das pessoas "desatentas" e pouco envolvida nas causas nacionais. Compreendemos que o ensino do canto orfeônico foi uma das estratégias utilizadas, em larga escala pelo governo de Getúlio Vargas, para aglutinar sentimentos de amor e veneração à pátria.

A professora Maria Cacilda Ribeiro Gonçalves anuncia que seria montado um aparelho de rádio em Teresina. ${ }^{5}$ A cidade apesar de não possuir nenhuma casa de instrução que se dedicasse ao ensino especial de música, contava com pianistas habilidosas, que poderiam irradiar o desenvolvimento artístico da música pelo Piauí. Entre as pianistas piauienses que se destacavam no período, a professora cita Creusa Serra e Silva, Yolanda Oliveira, Creusa Mendes, Maria Lúcia Abreu e Zila Paz. Estas teriam lutado contra as dificuldades do meio e triunfado à custa dos próprios esforços. O estado do Piauí, no Governo de Leônidas Melo, teria começado a se dotar de meios para o estudo especializado de música:

É por todos estes motivos que eu, animada pelos exemplos de patriotismo do ilustre governador Dr. Leônidas Melo, cuja boa vontade de nos dar um Piauhy melhor e mais grandioso tem sido posta à prova em altos comettimentos já realizados, que avultam pela grandeza e utilidade, venho, confiante no elevado espírito do esclarecido governante piauhyense e do Sr. Dr. Director do Departamento de Ensino, lembrar que na reforma por que vai passar a instrução pública do Estado, sejam incluídos, para serem ensinados nas escolas primárias, cursos obrigatórios de noções de theoria e solfejo, e formação de cantos coraes infantis. E, ainda, anexo à Escola Normal Official, a exemplo do que se tem feito n'outros Estados da Federação, um conservatório, para o estudo especializado da arte, sob direcção de um technico, no qual as nossas professoras normalistas, possam aperfeiçoar os conhecimentos adquiridos nos cursos anteriores (GONÇALVES, 1936, p. 1, 5).

No ano de 1936 o governador Leônidas Melo providenciou o contrato de um professor especializado no ensino de música, para isso contou com o auxílio do Governador do Rio

${ }^{5}$ No final da década de 1930, pouco antes da elite econômica e política anunciar o sonho de uma emissora de rádio em Teresina, os auto-falantes ou amplificadoras, localizados nas Praças Rio Branco e Pedro II, pareciam representar o novo e o moderno. Isso porque, segundo os cronistas de jornais locais, eles eram o próprio rádio, o rádio possível naquele momento de Teresina (SOLON, 2006, p. 175-176). As amplificadoras que se destacaram em Teresina naquele momento eram a Rádio Propaganda Sonora Rianil, inaugurada em 1939, e a Rádio Amplificadora Teresinense. A Rádio Educadora de Parnaíba foi a primeira emissora de rádio do Piauí, oficialmente instalada em 3 de maio de 1940. A primeira emissora de rádio sediada em Teresina, Rádio Difusora de Teresina, só entraria em funcionamento a partir de 1948. (NASCIMENTO, 2004). 
de Janeiro. Este teria atendido ao pedido do governo piauiense através do Serviço de Canto Orfeônico de Niterói (PIAUí, 1937, p. 36).

É interessante observar que a Câmara Federal tinha aprovado o projeto que tornava obrigatório o canto do Hino Nacional, no início das aulas, em todas as casas de instrução do Brasil, programas de rádio e comemorações públicas. Tudo isso seria motivo para determinar a criação dos cursos referidos, porque a música e a precisão dos seus ritmos, teriam uma linguagem forte, auxiliando o amor patriótico almejado na época getulista.

Outras disciplinas do currículo escolar, além do Canto Orfeônico, como História, Educação Física e Educação Moral e Cívica foram utilizadas na construção da memória patriótica, cada uma trazia suas especificidades. E os conteúdos programáticos traziam ensinamentos voltados para a formação da mentalidade cívica, sentimento de pertença à nação, corpo são e treinado para servir a Pátria (MELO, 2010, p. 108).

A perspectiva de memória utilizada na análise das fontes foi a de Maurice Halbwachs. Este autor entende a memória como um fenômeno coletivo e social (HALBWACHS, 2003). Entendemos a constituição da memória patriótica em território piauiense como algo que foi construído com o auxílio de segmentos, como os professores, políticos e intelectuais. Para Michael Pollak, em virtude das disputas políticas, a memória nacional passa por um processo de enquadramento com a escolha de datas e acontecimentos para serem celebrados e gravados na memória do povo (POLLAK, 1992, p. 204).

No ano de 1939, em conferência o Prefeito de Teresina, Lindolfo Monteiro, divulga as conquistas na área educacional que colocavam o Piauí em situação de destaque. Acentua o ensino de música e o de Canto Orfeônico na Escola Normal Oficial, e o curso de Educação Física (MONTEIRO, 1939, p. 1).

Em viagem ao Rio de Janeiro o Interventor Leônidas Melo cedeu uma entrevista ao Jornal "O Globo", como se vê na imagem seguinte: 


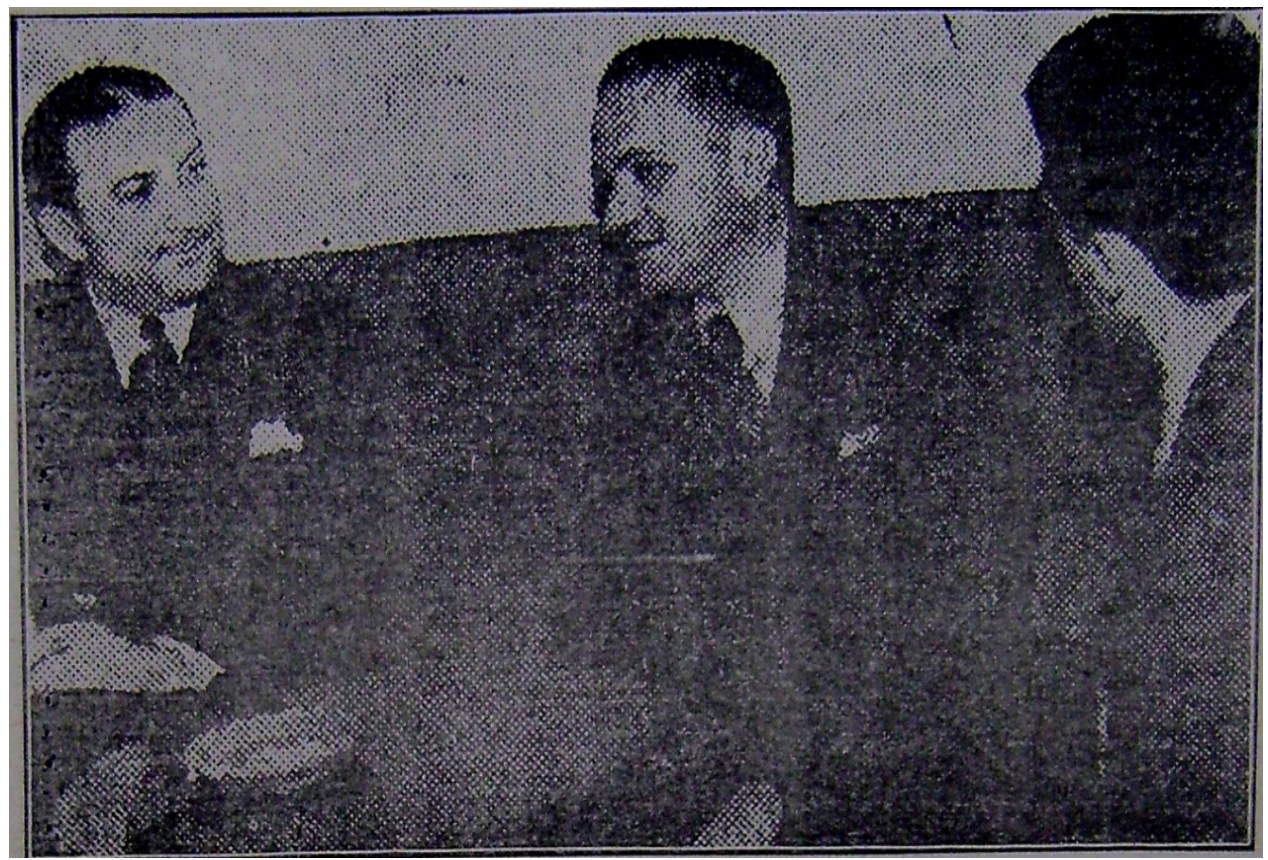

Fotografia 2 - Leônidas de Castro Melo cedendo entrevista ao jornal "O Globo".

Fonte: (FIEL, 1939, p. 5).

O jornal Diário Oficial noticiou a entrevista em suas páginas, o interventor falou sobre a construção de estradas, do amparo que desempenhava na saúde do estado, sobretudo com a construção do futuro Hospital Getúlio Vargas. Questionado sobre a instrução piauiense, ele enfatiza:

Como todo o Brasil, a instrução é, também, no Piauí, um dos nossos mais relevantes problemas. Dele não me hei descurado. Subvencionei vários colégios particulares, dando-lhes, até, mobiliário e material didáctico. Votei medidas de amparo à nossa Faculdade de Direito, conclui o grande edifício do Liceu Piauiense, institui o cinema educativo, conclui e inaugurei vários Grupos Escolares, instalei cerca de duzentas escolas nucleares, criei a Inspetoria de Educação Física. O ensino de música e o de Canto Orfeônico, na Escola Normal Oficial, tomou grande impulso: e cheguei, para tanto, a contratar técnicos para a orientação de tão importantes disciplinas (MELO, 1939, p. 5- 6).

A música, ao lado do cinema e do rádio, teria um papel central no esforço educativo e de mobilização, onde a linha divisória entre cultura e propaganda tornava-se tão difícil de estabelecer. A música contava com o maestro Heitor Villa-Lobos como o grande incentivador 
desta arte no país. Basicamente, o trabalho de Villa-Lobos consistia em desenvolver a educação musical artística através do canto coral popular, ou seja, canto orfeônico. O maestro fez diversas viagens percorrendo o interior paulista, realizando conferências e acabou formando um coral de dez mil vozes para o canto de hinos patrióticos. Nos folhetos distribuídos nessa cruzada, Villa-Lobos lembrava que, no estrangeiro, pensava-se que o brasileiro era desprovido de vontade e de espírito de cooperação, que vivia disperso, sem unidade de ação, sem a coesão necessária à formação de uma grande nacionalidade. No entanto, para o maestro, isso seria corrigido pela educação e pelo canto (SCHWARTZMAN; BOMENY; COSTA, 1984, p. 90-93).

Uma das entrevistadas desta pesquisa, D. Raimunda de Carvalho Sousa, ao ser questionada sobre a existência de aula de música na Escola Normal Oficial de Teresina, rememora:

Existia Dona Adalgisa, excelente professora de música, excelente pianista [...]. Era outra aula boa, outra disciplina boa. Ela ensinava os cantos, o Hino da Escola era um dos que ela mais batalhava. Agora o Hino Nacional 'nego' tinha que aprender o Hino Nacional pronunciando as palavras, não é ouviram dos 'piranga' não [risos]. Ave Maria! Ela batia muito sobre isso, [...] especialmente os hinos a Dona Adalgisa castigava, 'nego' tinha que saber pronunciar a letra do Hino Nacional direitinho (SOUSA, 2013).

De 1930 até final da década de 1970, em Teresina, Adalgisa Paiva notabilizou-se como maestrina, compositora, arranjadora, professora de piano e de Canto Orfeônico (MULHERES, 2012, p. 51). Outra entrevistada, dessa pesquisa, recordou a referida professora, "[...] tivemos aqui uma professora, ela fazia umas festas lindas, Adalgisa Paiva e Silva, maestrina, professora da Escola Normal, estudou com Villa-Lobos [...]. E ela era muito preparada, ela fazia o script da festa e ela ensaiava, ela era pequenininha [...]" (CORREIA, 2013).

Os momentos em que os hinos eram cantados nas escolas primárias, secundárias, normais e nos eventos cívico-militares no Piauí foram lembrados por todos os colaboradores desta pesquisa. Momentos utilizados para fortalecer o sentimento patriótico em território piauiense, ao envolver os estudantes diariamente em uma rotina de canto e de exaltação da Pátria, “[...] só entrava para as salas depois que cantasse o Hino Nacional, todo dia tinha que cantar [...], na entrada e na saída tornava cantar para poder ir embora. E nas comemorações todas eram obrigatórias o Hino Nacional" (AZEVEDO, 2013).

No entanto, apesar de enfatizado o caráter obrigatório do canto do Hino Nacional, essa atividade costumeiramente foi recordada com sentimento de saudade e de respeito ao país. Dona Terezinha de Jesus Rodrigues Sales Santos, que realizou o curso primário e ginasial em Parnaíba, recorda os hinos que aprendeu na escola:

[...] Eram os hinos comemorativos, inclusive aprendiam o hino da Independência, o hino da bandeira, o hino do Piauí, o hino da Parnaíba, por que a Parnaíba 
tem um hino, e o hino nacional. Aprendíamos cinco hinos e todos eles nós cantávamos "Salve o pendão da esperança" e aquela coisa todinha (SANTOS, 2013).

Os hinos pátrios e o ensino do canto orfeônico tornaram-se obrigatórios nas escolas brasileiras e ganhavam uma notoriedade maior nas comemorações cívico-patrióticas que aconteciam no Estado Novo. As músicas nacionalistas e hinos adquiriram um sentido ímpar, indo além dos ritos e performances presentes nas cerimônias públicas e no cotidiano escolar. $\mathrm{O}$ nacionalismo no Estado Novo tinha como finalidade despertar a brasilidade nos sentimentos mais íntimos das pessoas. Muitas daquelas canções ficaram gravadas para sempre na memória dos estudantes e professores do período (UNGLAUB, 2009, p. 125).

Mas nem só de aulas, prédios novos, material didático, disciplinas e festividades era feito o cotidiano dos estudantes piauienses no período. Devemos levar em consideração que se tratava de um cenário histórico envolvido pelo Estado Novo, e que o Interventor Leônidas Melo e o Diretor do Departamento de Ensino do Piauí, Anísio de Brito Melo, tinham a missão de levar uma imagem de educação a contento com os anseios do que era considerado ideal à ditadura de Getúlio Vargas.

É interessante perceber quanto os estabelecimentos de ensino em Teresina eram monitorados no período, principalmente os mais conceituados como a Escola Normal Oficial, Liceu Piauiense e o Ginásio "São Francisco de Sales", ${ }^{6}$ que tiveram diversas das suas portarias publicadas no jornal oficial do governo piauiense. Sobretudo quanto às punições sofridas pelos alunos que não se enquadravam no modelo de estudante obediente às normas dos estabelecimentos de ensino.

Um dos estabelecimentos educacionais que publicavam o expediente de cada mês no jornal "Diário Oficial" era o Liceu Piauiense, destacava as aulas que não haviam acontecido e os nomes dos professores faltosos. Outra prática recorrente de punição no Liceu Piauiense era a suspensão por vários dias por desrespeito aos funcionários do colégio:

Dia 17, Portaria $n^{\circ} 30$ - O Director do Lyceu Piauhyense usando das atribuições que lhe são conferidas pelo Regimento Interno, resolve aplicar a pena de suspensão por 3 dias, ao alumno da $1^{\circ}$ série Agnello de Oliveira Costa, por ter faltado com o devido respeito ao Inspector de Alumnos - Francisco de Moraes Brito. Cumpra-se. a) Agripino Oliveira - Director.

Dia 18, Portaria $n^{\circ} 32$ - O Director do Lyceu Piauhyense usando das atribuições que lhes são conferidas pelo Regimento Interno, resolve aplicar a pena de suspensão por seis (6) dias aos alumnos da $1^{\circ}$ série - Carino e Dorotheu Soares ${ }^{6}$ Colégio Diocesano São Francisco de Sales foi criado em 1906, inicialmente destinado exclusivamente ao público masculino,
aceitava alunos internos, semi-internos e externos (QUEIROZ, 2008. p. 69). 
Ribeiro, por terem desrespeitado ao Sr. Secretário do Lyceu. Cumpra-se. a) Agripino Oliveira - Director (LYCEU, 02 out. 1935, p. 5).

Dia 25, Portaria $n^{\circ} 34$ - O Director do Lyceu Piauhyense usando das atribuições que lhes são conferidas por lei, resolve aplicar a pena de suspensão por trinta dias ao aluno da $1^{\circ}$ série - Dorotheu Soares Ribeiro, por ter desacatado o Sr. Secretário e bem assim suspender por 10 dias o alumno da mesma série - Sadoc Ferreira Lima, por ter maltratado seu colega menor. Cumpre-se. a) João Pinheiro - Director (LYCEU, 09 out. 1935, p. 4).

Percebemos que o Colégio, responsável pelo ensino secundário em Teresina, seguia um Regimento Interno, e que a penalidade preferida aplicada pelos Diretores era a suspensão, que chegava a durar um mês inteiro, no caso do aluno Dorotheu Soares Ribeiro, que era reincidente em desrespeitar o secretário do Liceu Piauiense. Outras formas de desvios de comportamento, como agressões aos colegas menores, foram alvos de suspensão.

No expediente do mês de outubro de 1935 do Liceu Piauiense, foi observado que havia práticas, como desobediência, absenteísmo e agitação nas aulas de Música e de Educação Física, por parte de alguns estudantes do estabelecimento de ensino secundário, que geravam punições:

Portaria $\mathrm{n}^{0} 37$ - O Director do Lyceu Piauhyense determina aos inspetores de alumnos, que, de acordo com o art. 57 do Regimento Interno, não permitam a entrada de alumnos no Estabelecimento, sem estarem devidamente uniformizados, e bem assim, que seja obrigatória a frequência das aulas de música e Educação Physica. Cumpra-se. a) João Pinheiro - Director (LYCEU, 16 out. 1935, p. 5).

Portaria $n^{\circ} 47$ - O Director do Lyceu Piauhyense usando das atribuições que lhes são conferidas por lei, e tendo em vista a parte escripta que lhe foi apresentada pelo inspetor da $1^{\circ}$ série - Francisco Moraes Brito, resolve suspender por dez dias, os alumnos - Aniceto Sousa, Antonio Luiz Fernandes Torres, Alprim da Silva Ary, Antonio José da Costa, Afonso Ferro Gomes, Antonio Farias Filho, Afrânio Clementino Martins, Benedicto Torres, Benedicto Ribeiro de Britto e José Gonçalves Costa, por estarem promovendo algazarra em plena aula de música. Cumpra-se. a) João Pinheiro - Director (LYCEU, 29 out. 1935, p. 4).

Entende-se que o Diretor João Pinheiro estava levando os alunos a cumprir o Regimento Interno da instituição, mas também devemos considerar que era durante as aulas de Música e de Educação Física que os estudantes entravam em contato com os diversos hinos e cânticos patrióticos usados em comemorações públicas e nas demais festividades realizadas na escola. A Educação Física era outra disciplina que favorecia o acompanhamento e o doutrinamento 
da educação no período, sobretudo quando teriam que ensaiar as marchas, coreografias e números diversos apresentados nas festividades escolares.

O que leva a crer, a partir das portarias referidas, que nem todos os estudantes estavam interessados em participar dessas aulas. E que mesmo participando, não significava que eles estavam totalmente envolvidos com as normas e ensinamentos cívicos divulgados naqueles momentos, que deveriam ser de amor à Pátria e de ordem, acima de tudo.

A Escola Normal Oficial em Teresina era outra instituição de ensino que tinha a sua rotina divulgada no jornal "Diário Oficial", dando destaque ao funcionamento das aulas que ocorriam e das que não aconteciam, inclusive publicava o nome das normalistas faltosas de cada dia. Para além do ambiente interno da Escola Normal, o controle sobre as alunas era tão intenso que, mesmo estando fora da escola, elas eram punidas quando desobedeciam ao Regulamento Geral do Ensino. Uma punição sofrida pela normalista Dulce de Sousa Martins ganha espaço no jornal:

Portaria ${ }^{0} 22$ - A Directora da Escola Normal Official usando das atribuições e do Regulamento Geral do Ensino, em vigor, resolve suspender por 5 dias, a contar de hoje, a alumna da $5^{\circ}$ série deste Estabelecimento, Dulce de Sousa Martins, por ser encontrada na rua uniformizada, sem a respectiva boina. Publique-se (ESCOLA, 1935, p. 4).

A partir do exposto, podemos inferir que as alunas da Escola Normal Oficial seguiam diversas recomendações e teriam que ter um comportamento condizente com o Regulamento Geral do Ensino e com a postura que era exigida da mulher no período, passando, até mesmo, pelo uniforme que deveria estar impecável e completo, inclusive fora do ambiente da Escola Normal.

Através das portarias das escolas analisadas percebemos que seus diretores, inspetores, secretários, foram grupos que estiveram aliados ao Diretor do Departamento de Ensino. Todos estes preocupados em enquadrar os estudantes piauienses em condutas e normas compatíveis com o modelo de obediência aclamado pelo Estado Novo. No entanto, compreendemos quanto era difícil para os alunos estar o tempo todo monitorados e alinhados aos regimentos e regulamentos da época, tudo isso não impediu que os estudantes buscassem outras formas de participar do cotidiano escolar e se divertissem em meio a tantas ordens.

Um exemplo de agitação podemos perceber no ambiente escolar nas travessuras que algumas normalistas faziam, porém logo eram levadas a responder pelas desordens e os tumultos causados. Dona Raimunda de Carvalho Sousa, que era mais comportada, recorda a postura de sua irmã Emília, que chegou a incomodar a Diretoria da Escola Normal no período:

Tinha muita aluna brincalhona [risos]. Que fazia muita brincadeira dentro da sala de aula, mas quando o professor chegava tava todo mundo direitim 
comportado. Agora tinha aluna que era danada mesmo fazia muita presepada dentro da sala de aula. Na minha turma mesmo tinha gente que fazia graça, brincava e tudo. Mas não era o tipo de brincadeira que prejudicasse ninguém, era uma brincadeira sadia, tinham delas que gostavam de dançar. Eu não, eu era muito recatada, eu era muito quieta, não gostava muito de confusão não. Já minha irmã a Emília, estudava numa turma anterior a minha, eu só vivia na diretoria atendendo chamado por causa das pinturas dela e uma colega que ela tinha que era a Ildete, [...] elas faziam muita danação [risos]. Um dia elas... As brincadeiras maiores que elas faziam, por exemplo, nesse dia, a Ildete e a Miloca [Emília] foram lá na Praça da Bandeira encheram a saia de pedra e subiram a escada dizendo é hoje, é hoje que nós matamos um, nós vamos matar um. Entraram pra sala delas [...], ai fecharam a porta e começaram pa pa pa, eram pedrada de todo tamanho querendo matar morcego, dentro da sala de aula [risos]. Ô mais nesse dia eu tive raiva da Miloca, a minha irmã, ai eu fui para a diretoria ai a Enid, que era secretária, "mas Emília como é? sua irmã é tão comportada, é uma menina tão boa na turma, todo mundo gosta dela, e você é desse jeito? Só vive aqui", só vivia na diretoria por causa de brincadeira na sala de aula (SOUSA, 2013).

Um professor que causava bastante incômodo para à ex-aluna da Escola Normal Oficial, Dona Raimunda de Carvalho Sousa, era o professor Valdir Gonçalves, que ministrou a disciplina de História. Ela recorda as aulas do professor com um sentimento de medo, que chegava a comprometer seu aprendizado:

Ah tem um que eu não esqueço ele nunca, ele era muito austero, era muito compenetrado, importante de tudo, era o Dr. Valdir Gonçalves ainda hoje eu me lembro. Ô homem sei lá... eu não aprendia aquela matéria dele mais era de jeito nenhum, não conseguia, que eu tinha um medo, tinha um pavor. Quando dizia: "aula de História”, todo mundo... eu já tava sentada na minha carteira me tremendo fazia era tempo com medo dele [risos]. Eu era reprovada na disciplina dele não tinha era jeito, eu passei depois que ele saiu, que a Dona Elisinha entrou, ai é que eu passei a estudar e aprender História. Mas com ele eu não aprendia não, que eu tinha um medo dele, eu tinha era pavor, quando ele pisava no corredor a nossa sala era a última do lado, em cima da Escola Modelo... Aquilo ele tava dando aula, se caísse um lápis no chão não era para apanhar não, ficava lá no chão até o fim da aula pra depois você apanhar, ninguém podia nem se mexer, era desse jeito. As provas geralmente três questões, duas perguntas e uma dissertação. Era horrível. [risos]. Não era pergunta pra marcar, certo ou errado, não. Especialmente História, ele escolhia o assunto e a gente tinha que 
dissertar sobre aquele assunto, geralmente era assim, especialmente as provas parciais, eram muito rigorosas, 'moleque' tinha que saber disciplina, se não soubesse, já viu, era reprovado. Reprovado mesmo, ficava pra segunda época, era confusão maior do mundo, e a gente não aprendia mesmo... Tinha as alunas que aprendiam, tinham alunas grau 10 na turma, mas a maioria não (SOUSA, 2013).

Através da memória da depoente, percebemos que a postura do professor referido causava mal estar nela, que passou a aprender a disciplina quando o professor Valdir Gonçalves foi substituído. A presença e a proximidade da aula do professor causavam medo que dificultava o aprendizado da disciplina. As provas de História eram outro momento que causava angústia na entrevistada e em demais alunas da Escola Normal, segundo ela, nem todas as alunas eram "grau 10" na sua turma.

\section{Considerações Finais}

O Estado Novo marcou a trajetória política brasileira, era caracterizado pela centralização política na figura de Getúlio Vargas e pelo caráter repressivo que tentava ocultar as contradições do regime. Esse período foi marcado, também, pelo intuito do fortalecimento do sentimento de identidade nacional e a adesão dos brasileiros na construção da memória cívica. $O$ Departamento de Imprensa e Propaganda se encarregou de divulgar uma imagem que favorecia o novo regime. Tinha como uma de suas missões disseminar a cultura nacionalista e organizar as comemorações patrióticas que fizeram parte do cotidiano de inúmeros brasileiros. Dessa forma, os interesses do chefe na nação estariam sendo levados a diversas regiões do país.

O interventor piauiense, Leônidas de Castro Melo, era representado como o governante que estava incentivando a educação primária, secundária, normal e superior no Piauí. Durante sua gestão foram inaugurados diversos Grupos Escolares, que representava o novo tipo de prédio escolar, dentro das prerrogativas da modernização do Estado Novo.

Nesta pesquisa analisamos como a instrução piauiense, as solenidades cívicas, o ensino de música e a prática do canto orfeônico foram utilizados pelo governo local na busca da formação da consciência patriótica da juventude escolar piauiense. Percebemos que os estabelecimentos de ensino, professores e políticos estiveram atentos às solicitações, que vinham do governo nacional, em cooperar com a constituição do civismo.

$\mathrm{O}$ ensino dos hinos pátrios foram largamente difundidos pelos estabelecimentos de ensino do período. A juventude era ensinada, desde cedo, a amarem e reverenciarem os símbolos nacionais e a memória de brasileiros que se destacaram em defesa do país. A partir das entrevistas com ex-alunos do Liceu Piauiense, Escola Normal de Teresina, e de outras instituições, notamos o quanto esses momentos ficaram gravados em suas memórias. Muitos 
desses ex-alunos, ao recordarem dos momentos, cantavam as letras dos hinos e relembravam detalhes dos ensaios.

Ao longo da pesquisa, percebemos o rígido controle que os estudantes eram submetidos nas escolas piauienses, sobretudo nas aulas, nos ensaios de música, nas normas regimentais dos estabelecimentos de ensino. No entanto, visualizamos outras formas vivências escolares que driblavam a vigilância dos normatizadores a serviço do Estado. Os comportamentos juvenis que passavam pela descontração, infringência de regras e pelas desordens eram apontados como um ameaça para o ambiente que se pretendia construir no Piauí estadonovista.

Nesse sentido, podemos compreender que o interventor federal e as escolas piauienses estiveram irmanados na busca de cooperação e obediência ao Estado Novo. Entretanto, a partir das fontes analisadas, destacamos outras formas de experiências que contrariavam o modelo de estudante ordeiro e submisso ao regime.

\section{BIBLIOGRAFIA}

A INAUGURAÇÃO do edifício do Grupo Escolar "Cônego Acilino" e a visita ao Hospital São Vicente de Paula”. Diário Oficial, Teresina, ano IX, n. 220, 26 set. 1939, p. 1.

A INAUGURAÇÃo do Grupo Escolar e Jardim Público. Diário Oficial, Teresina, ano V, n. 275, 11 dez. 1935, p. 8.

AZEVEDO, Edison Rodrigues de. Entrevista concedida a José de Arimatéa Freitas Aguiar Júnior. Teresina, 05 out. 2013.

COLÉGIO “Sagrado Coração de Jesus”. Diário Oficial, Teresina, ano VI, n. 197, 02 set. 1936, p. 1, 12.

CORREIA, Maria Genovefa de Aguiar Moraes. Entrevista concedida a José de Arimatéa Freitas Aguiar Júnior. Teresina, 03 jul. 2013.

ESCOLA Normal - Expediente do mês de Outubro. Diário Oficial, Teresina, ano V, n. 243, 05 nov. 1935, p. 4.

GOMES, Ângela Maria de Castro. A Invenção do Trabalhismo. 3 ed. Rio de Janeiro: Editora FGV, 2005.

GONÇALVES, Maria Cacilda Ribeiro. As Artes no Brasil. Diário Oficial, Teresina, ano VI, 25 jul. 1936, p. 1 e 5.

HALBWACHS, Maurice. A Memória Coletiva. São Paulo: Centauro, 2003. 
LOPES, Antônio de Pádua Carvalho. Escola e Cidade: as festividades escolares no Piauí. In: IBIAPINA, Ivana Maria Lopes de Melo; CARVALHO, Maria Vilaní Cosme de (Orgs). A pesquisa como mediação de práticas socioeducativas. Teresina: EDUFPI, 2007, v. 2. p. 11-20.

LOPES, Sales. A Inauguração do edifício do Grupo Escolar “Cônego Acilino" e a visita ao Hospital São Vicente de Paula”. Diário Oficial, Teresina, ano IX, n. 220, 26 set. 1939, p. 1-3.

LYCEU Piauhyense- Expediente do mês de outubro. Diário Oficial, Teresina, ano V, n. 229, 16 out. 1935, p. 5.

LYCEU Piauhyense- Expediente do mês de outubro. Diário Oficial, Teresina, ano V, n. 240, 29 out. 1935, p. 4.

LYCEU Piauhyense. Diário Oficial, Teresina, ano V, n. 217, 02 out. 1935, p. 5.

LYCEU Piauhyense. Diário Oficial, Teresina, ano V, n. 223, 09 out. 1935, p. 4.

MELO, Leônidas de Castro. Fiel ao seu povo e a sua profissão! Diário Oficial, Teresina, ano IX, 21 jun. 1939, p. 5-6.

MELO, Salânia Maria Barbosa. A Construção da Memória Cívica: espetáculos de civilidade no Piauí. (1930-1945). Teresina: EDUFPI, 2010.

MONTEIRO, Lindolfo do Rêgo. As Comemorações do Quarto Aniversário do Governo. Diário Oficial, Teresina, ano IX, n. 103, 09 maio 1939, p. 1.

MONTEIRO, Lindolfo do Rêgo. Instrução Pública. Diário Oficial, Teresina, ano IX, n. 31, 06 fev. 1939, p. 1- 4.

MULHERES da História. Revista Cidade Verde: o Piauí com todas as letras. Ano 01, Edição 27, 11 de mar. 2012. p. 51.

NASCIMENTO, Francisco Alcides do. A cidade sob o fogo: modernização e violência policial em Teresina- (1937-1945). Teresina: FCMC, 2002.

NASCIMENTO, Francisco Alcides do. História e memória da Rádio Pioneira de Teresina. Teresina: Alínea Publicações Editora, 2004.

PIAUÍ. Governo 1935-1945. Mensagem apresentada a Assembleia Legislativa do Estado do Piauhy, a $1^{\circ}$ de junho de 1937, pelo Governador Leônidas de Castro Mello referente ao ano de 1936. Teresina: Imprensa Oficial, 1937. p. 36. 
PIAUÍ. Governo 1935-1945. Relatório apresentado ao Presidente da República pelo Interventor Leônidas de Castro Melo referente ao ano de 1937. Teresina: Imprensa Oficial, 1938. p. 85-86.

POLLAK, Michael. Memória e identidade social. In: Estudos históricos. Rio de Janeiro, v 5, n. 10, 1992. p. 204.

QUEIROZ, Teresinha de Jesus Mesquita. Educação no Piauí (1880-1930). Imperatriz - MA: Ética, 2008.

SANTOS, Terezinha de Jesus Rodrigues Sales. Entrevista concedida a José de Arimatéa Freitas Aguiar Júnior. Teresina, 02 out. 2013.

SCHWARTZMAN, Simon. Estado Novo, um Auto-retrato (Arquivo Gustavo Capanema). Brasília, CPDOC/FGV, Editora Universidade de Brasília, 1983.

SCHWARTZMAN, Simon; BOMENY, Helena Maria Bousquet; COSTA, Vanda Maria Ribeiro (Orgs). Tempos de Capanema. Rio de Janeiro: Paz e Terra; São Paulo: Editora da Universidade de São Paulo, 1984.

SILVA, Idalina Ferreira da. Discurso pronunciado pela professora Idalina Ferreira da Silva na cerimônia de inauguração do Grupo Escolar "Cônego Acilino" em Valença. Diário Oficial, Teresina, ano IX, n. 220, 26 set. 1939, p. 3.

SOLON, Daniel Vasconcelos. Novos sons se espalham por Teresina: os alto-falantes e o processo de modernização da cidade (1939-1952). In: NASCIMENTO, Francisco Alcides do; SANTIAGO JR, F. C. Fernandes (Org.). Encruzilhadas da história: rádio e memória. Recife: Bagaço, 2006. p. 167196.

SOUSA, Raimunda de Carvalho. Entrevista concedida a José de Arimatéa Freitas Aguiar Júnior. Teresina, 07 jun. 2013.

UNGLAUB, Tânia Regina da Rocha. A prática do Canto Orfeônico e cerimônias cívicas na consolidação de um nacionalismo ufanista em terras catarinenses. Revista Linhas, Revista do Programa de Pós-Graduação em Educação. Florianópolis, v.10, n. 01, jan./jun. 2009. p. 105-127. 


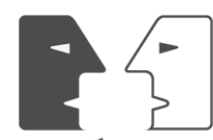

ANTÍTESES 